\title{
Dynamics of Calcaemia, Phosphoraemia and Magnesaemia at Different Prepartal Intakes of Calcium in Dairy Cows
}

\author{
T. ZELENÝ ${ }^{1}$, J. ZELENÝ1 ${ }^{1}$, V. KROUPOVÁ ${ }^{2}$, P. SLAVÍK ${ }^{3}$ \\ ${ }^{1}$ Veterinary Centre s. r. o., Sušice, Czech Republic \\ ${ }^{2}$ South Bohemian University in České Budějovice, Agricultural Faculty, České Budějovice, Czech Republic \\ ${ }^{3}$ Faculty of Veterinary Hygiene and Ecology, University of Veterinary Medicine \\ and Pharmaceutical Sciences, Brno, Czech Republic
}

Received May 24, 2005

Accepted March 13, 2007

\begin{abstract}
Zelený T., J. Zelený, V. Kroupová P. Slavík: Dynamics of Calcaemia, Phosphoraemia and Magnesaemia at Different Prepartal Intakes of Calcium in Dairy Cows. Acta Vet Brno 2007, 76: $187-193$.

The objective of this study was to compare the efficiency of high and low Ca intake in cows with analytically defined levels of calcaemia, phosphoraemia and magnesaemia in the prepartal period, on their postpartal changes important for the diagnosis of postpartal diseases.

In dairy cows (Czech Pied cattle) receiving a winter feed ration, the prepartal intake of Ca was adjusted from day 241 of pregnancy to $80 \%$ in group $\mathrm{A}(\mathrm{n}=15)$ and to $160 \%$ of the standard in group $\mathrm{B}(\mathrm{n}=9)$. In both groups the concentrations of $\mathrm{Ca}, \mathrm{P}$ and $\mathrm{Mg}$ in blood serum were measured at the beginning of experimental diets, on day 12 before the expected parturition, and on days 1,2, 3 and 4 after parturition.

At the beginning of the experiment (42 days before parturition) the value of calcaemia was $1.82 \pm 0.10 \mathrm{mmol} \cdot \mathrm{l}^{-1}$, phosphoraemia $1.61 \pm 0.37 \mathrm{mmol} \cdot \mathrm{l}^{-1}$ and magnesaemia $0.74 \pm 0.6 \mathrm{mmol} \cdot \mathrm{l}^{-1}$ of blood serum. After the 30-day feeding of experimental diet (day 12 before the expected parturition) higher hypocalcaemia was recorded in group A persisting to day 3 post partum. Phosphoraemia and magnesaemia were at the lower limit of reference values only from day 12 before the expected parturition to day 4 post partum. In group A three cows became recumbent until day 3 post partum with a decrease in magnesaemia below $0.5 \mathrm{mmol} \cdot \mathrm{l}^{-1}$.

Phosphoraemia and magnesaemia were at the lower limit of reference values only from day 12 before the expected parturition to day 4 post partum. In group A three cows became downed until day 3 post partum with a decrease in magnesaemia below $0.5 \mathrm{mmol} \cdot \mathrm{l}^{-1}$.

In group B with $160 \%$ intake of $\mathrm{Ca}, 12$ days before the expected parturition calcaemia amounted to $2.20 \pm 0.27 \mathrm{mmol} \cdot \mathrm{l}^{-1}$ and hypocalcaemia ranging from $1.60 \pm 0.45$ to $1.80 \pm 0.26 \mathrm{mmol} \cdot \mathrm{l}^{-1}$ of blood serum persisted from day 1 to day 4 post partum. The average level of phosphoraemia in group B was maintained above $1.80 \mathrm{mmol} \cdot \mathrm{l}^{-1}$ and magnesaemia was within the range of 0.93 $1.21 \mathrm{mmol} \cdot \mathrm{l}^{-1}$ of blood serum.

The results of the nutrition experiment document that for the prepartal adjustment of Ca intake aimed at a reduction in the incidence of the postpartal downer cow syndrome, it is necessary to determine calcaemia, phosphoraemia and magnesaemia in late-pregnant cows. In hypocalcaemia, hypophosphoraemia and especially hypomagnesaemia the prepartal diet with $80 \%$ coverage of $\mathrm{Ca}$ need leads to a higher risk of the downer cow syndrome accompanied by higher hypomagnesaemia.
\end{abstract}

Nutrition, blood serum, Ca, $P, M g$, hypocalcaemia, downer cow syndrome

Disorders of $\mathrm{Ca}, \mathrm{P}$ and $\mathrm{Mg}$ metabolism are still a health risk in dairy cows in spite of various dietetic preventive measures taken mainly in the prepartal period. It is most frequently hypocalcaemia in the first days after parturition that leads to the downer cow syndrome. Sometimes hypocalcaemia may be accompanied by hypophosphoraemia (Goff et al. 1996) or irregularly increased magnesaemia (Doležel et al. 1991; Kudláč et al. 1995). Different prepartal measures are recommended to reduce the undesirable incidence of postpartal hypocalcaemia: a decrease in the $\mathrm{Ca}$ intake to less than $0.5 \%$ of dry matter

Address for correspondence: 
(Goff and Horst 1993; Gebauer 1963; Hallgren 1965); an increase in Ca intake to $1.3 \%$ of dry mater; high doses of vitamin $\mathrm{D}_{3}$ (Hor st et al. 2003); acidogenic diets increasing the presence of ionised calcium by the application of phosphates (Goff and Horst 2003) or $\mathrm{MgSO}_{4}$ (Stockdale 2004). The narrowing of the $\mathrm{Ca}$ : P ratio is also an efficient measure.

Stojevic et al. (2004) reported that the level of phosphoraemia in dairy cows decreased later, in the course of lactation. Phosphoraemia dynamics in the peripartal period was studied by Vojtíšek et al. (1991) and Hennig (1972), who arrived at different results. Kudláč et al. (1995) described a decrease in phosphoraemia in cows in the peripartal period in connection with a retained placenta.

In the foothills it is necessary to provide higher doses of phosphates in herds of dairy cows due to a high proportion of bulk feeds. If the quality of these feeds is lower, the low level of phosphoraemia becomes urgent also at the onset of lactation.

Hypomagnesaemia occurs most frequently in older cows suffering from pasture tetany (Underwood and Suttle 2001). In the course of lactation the average values of magnesaemia increase from the $25^{\text {th }}$ day after parturition (Doležel et al. 1991). The finding of Littledike and Goff (1987) indicated a relationship between hypocalcaemia and hypomagnesaemia; they concluded that severe hypomagnesaemia decreased the secretion of PTH at moderate hypocalcaemia.

The objective of the nutrition experiment was to compare the effects of high and low intake of $\mathrm{Ca}$ in dairy cows in the prepartal period during their transition to winter ration on postpartal changes in calcaemia, phosphoraemia and magnesaemia as important parameters of differential diagnostics of postpartal diseases.

\section{Materials and Methods}

The effects of different $\mathrm{Ca}$ intake in the prepartal period on the concentration of $\mathrm{Ca}, \mathrm{P}$ and $\mathrm{Mg}$ in the blood serum of dairy cows until the fourth day after parturition were studied in a herd of 115 cows of the Czech Pied breed at 7 years of age on average in groups A and B. Average daily milk yield was 181 in group A and 171 in group B. The average age of cows was actually higher than the national average because during privatisation the producers received animals born mainly in 1996 that were not perspective animals for cooperative farms. These animals were suitable for the experiment because the risk of the downer cow syndrome increases with age. The farm at Horní Staňkov is situated in Western Bohemia in the Sušice area at an altitude of $750 \mathrm{~m}$ above the sea level. The cows were kept on straw bedding in a stanchionless cowshed.

Average milk yield per standardised lactation was $5500 \mathrm{l}$. A minimum frequency of mastitis, endometritis, retained placenta, periparturient paresis and pododermatitis documents the good health of animals and proper animal hygiene. The service period was 98 days.

Pasture forage with a higher proportion of white clover ad libitum was the main component of the summer ration from May 3 to October 10,2003. Besides grazing the cows received $2 \mathrm{~kg}$ of hay daily and mineral supplement Vitamix S3. The total daily intake of calcium was $86 \mathrm{~g}$, of phosphorus $44.5 \mathrm{~g}$ and magnesium $26 \mathrm{~g}$. The winter ration from October 11, 2003 to November 1, 2003 was composed of $15 \mathrm{~kg}$ grass haylage, $5 \mathrm{~kg}$ hay and $200 \mathrm{~g}$ Vitamix S3. The content of nutrients in this ration was as follows: $\mathrm{Ca} 60 \mathrm{~g}, \mathrm{P} 38 \mathrm{~g}$ and $\mathrm{Mg} 17 \mathrm{~g}$, and corresponded in general to the requirements for macroelements according to Sommer et al. (1994). The content of nutrients in bulk feeds was determined analytically in a laboratory of the Proagro a.s. company in Klatovy. The content of macroelements in the mineral supplement (MS) was based on the manufacturer's indication (Biofaktory Praha s.r.o.). The diet from October 11, 2003 to November 1, 2003 was considered as a transition period. At the beginning of the experiment on $1^{\text {st }}$ November 2003 only the supplementation of minerals changed when MS Vitamix S0 was used for group A and Vitamix S8 for group B. Table 1 shows the components of feed ration of these groups and the level of macroelement intake in group A (with $80 \%$ Ca intake). Table 2 shows the level of macroelement intake in group $\mathrm{A}$ and $\mathrm{B}$.

The experiment lasted from November 1, 2003 to January 31, 2004. At the beginning of the experiment two experimental groups $(\mathrm{A}=15 ; \mathrm{B}=9)$ of pregnant dairy cows were established (42 days before the expected parturition). The size of the groups was determined by the housing facilities: each group had the same area of resting place and the same number of feeding places per head. Group A received a diet with MS Vitamix S0 without calcium while group B was applied Vitamix S8 with $180 \mathrm{~g} \mathrm{Ca} / \mathrm{kg}$ (Table 1).

The collection of blood samples from the vena jugularis and determination of calcaemia, phosphoraemia and magnesaemia were carried out on the day of the beginning of the experiment, 12 days before the expected parturition and on days 1,2, 3 and 4 post partum except for cow No. 27711 that died on day 2 after parturition.

$\mathrm{Ca}$, inorganic $\mathrm{P}$ and $\mathrm{Mg}$ in blood serum were determined in a biochemical analyser Selektra by colorimetric 
methods using reagents of DOT Praha Company. To determine $\mathrm{Ca}$ and $\mathrm{Mg}$, the reagent Arsenaso II was used while inorganic phosphorus was determined with ammonium molybdate.

For the statistical processing of data $t$-test was used to determine the difference between groups, whereas paired $t$-test in the program STAT plus was applied to evaluate the peripartal dynamics (Matoušková et al. 1992).

Table 1. Components of feed ration for dairy cows before and after parturition $(\mathrm{kg} / \mathrm{head} / \mathrm{day})$

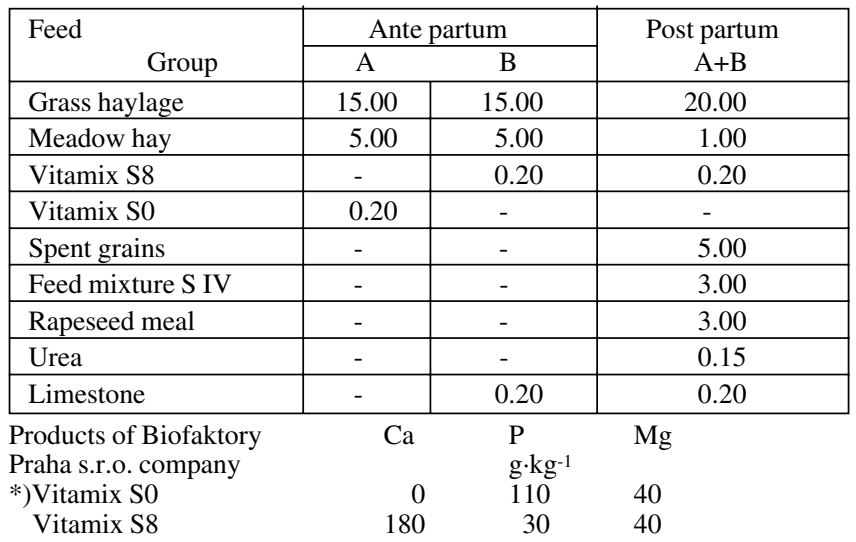

\section{Results}

At the beginning of the experiment after 20-day transition to the winter ration, the level of calcaemia was $1.82 \pm 0.10 \mathrm{mmol} \cdot \mathrm{l}^{-1}$ of blood serum in group A and B. In group A this value was maintained from 12 days ante partum to day 2 post partum. In the next two days there was a statistically non-significant increase to $2.20 \mathrm{mmol} \cdot \mathrm{l}^{-1}$ on average with a wide individual range from 1.90 to $2.40 \mathrm{mmol} \cdot \mathrm{l}^{-1}$ of blood serum.

In group B the development of calcaemia was different from day 30 after the beginning of the experiment. It increased non-significantly to $2.20 \pm 0.27 \mathrm{mmol} \cdot \mathrm{l}^{-1} 12$ days ante partum. In the next days to day 4 post partum there was a permanent decrease to $1.60 \pm 0.43 \mathrm{mmol} \cdot \mathrm{l}^{1}$ on average.

At the beginning of the experiment the average level of phosphoraemia (Fig. 2) was 1.60 $\pm 0.37 \mathrm{mmol} \cdot \mathrm{l}^{-1}$ of blood serum in groups A and B. In group A, it decreased non-significantly to $1.70 \pm 0.58 \mathrm{mmol} \cdot \mathrm{l}^{-1}$ a day post partum. In the next days a non-significant increase to 2.10 $\pm 0.48 \mathrm{mmol} \cdot \mathrm{l}^{-1}$ of blood serum was measured.

In group B phosphoraemia was non-significantly but permanently higher until day 3 post partum compared to group A.

At the beginning of the experiment the average value of magnesaemia in groups $\mathrm{A}$ and $\mathrm{B}$ was $0.74 \pm 0.06 \mathrm{mmol} \cdot \mathrm{l}^{-1}$ (Fig. 3). In group A magnesaemia decreased to the value of 0.59 $\pm 0.13 \mathrm{mmol} \cdot \mathrm{l}^{-1}$ within 30 days after the beginning of the experiment (12 days ante partum). Hypomagnesaemia persisted from day 4 post partum.

In group B magnesaemia amounted to $0.96 \pm 0.24 \mathrm{mmol} \cdot \mathrm{l}^{-1} 12$ days ante partum; in the next days after parturition it increased non-significantly until day 4 , when it reached the value of $1.21 \pm 0.57 \mathrm{mmol} \cdot \mathrm{l}^{-1}$, which was significantly higher compared to group A.

The downer cow syndrome post partum was observed in three animals in group A only. In two animals the intravenous administration of $\mathrm{Ca}$ (Calcium gluconicum - $500 \mathrm{ml}$ ), $\mathrm{P}$ (Glyphostan - $250 \mathrm{ml}$ ) and vitamins (ADE oleosum - $50 \mathrm{ml}$ ) was a successful treatment. Table 3 shows the specific values of macroelements in downer dairy cows. Cow No. 27711 that died, had lower values of calcaemia $\left(1.30 \mathrm{mmol} \cdot \mathrm{l}^{-1}\right)$ and magnesaemia $\left(0.60 \mathrm{mmol} \cdot \mathrm{l}^{-1}\right)$ compared to the successfully treated animals. 
Table 3. An overview of calcaemia, phosphoraemia and magnesaemia in downer dairy cows post partum

\begin{tabular}{|c|c|c|c|c|}
\hline Cow No. & Sampling No. & $\mathrm{Ca}$ & $\mathrm{P}$ & $\mathrm{Mg}$ \\
\hline \multirow{3}{*}{27711} & 1 & 1.70 & 1.50 & 0.50 \\
\cline { 2 - 5 } & 2 & 1.30 & 2.30 & 0.60 \\
\cline { 2 - 5 } & $3^{*}+$ & 2.30 & 1.40 & 0.50 \\
\hline \multirow{5}{*}{29752} & 1 & 1.40 & 1.20 & 0.90 \\
\cline { 2 - 5 } & 2 & 1.70 & 1.20 & 1.20 \\
\cline { 2 - 5 } & 3 & 1.60 & 1.30 & 1.20 \\
\cline { 2 - 5 } & $4^{*}$ & 1.50 & 1.60 & 0.40 \\
\cline { 2 - 5 } & 5 & 2.20 & 2.60 & 0.80 \\
\hline \multirow{5}{*}{26011} & 1 & 2.00 & 1.50 & 0.70 \\
\cline { 2 - 5 } & 2 & 1.30 & 1.50 & 0.40 \\
\cline { 2 - 5 } & 3 & 1.90 & 1.50 & 0.40 \\
\cline { 2 - 5 } & $4 *$ & 2.10 & 1.90 & 0.30 \\
\cline { 2 - 5 } & 5 & 2.30 & 2.10 & 0.50 \\
\hline
\end{tabular}

Sampling 1= 12 days ante partum, sampling 2 - day 1, sampling 3 - day 2 , sampling 4 - day 3 , sampling 5 - day 4 post partum

* Cow No. 27711 died on day 2 post partum, * day of becoming downed, + - mortality

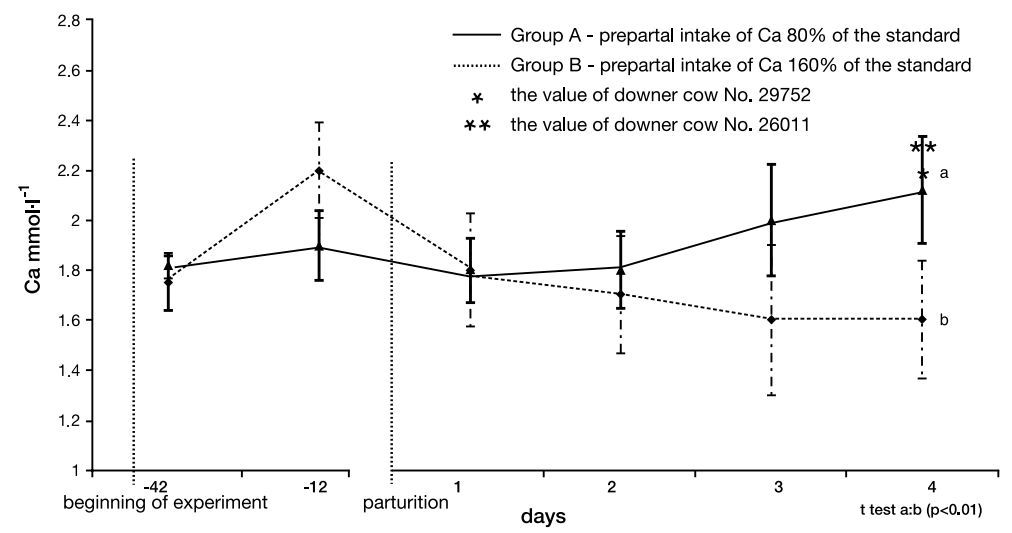

Fig. 1. Pre- and postpartal dynamics of calcaemia in dairy cows

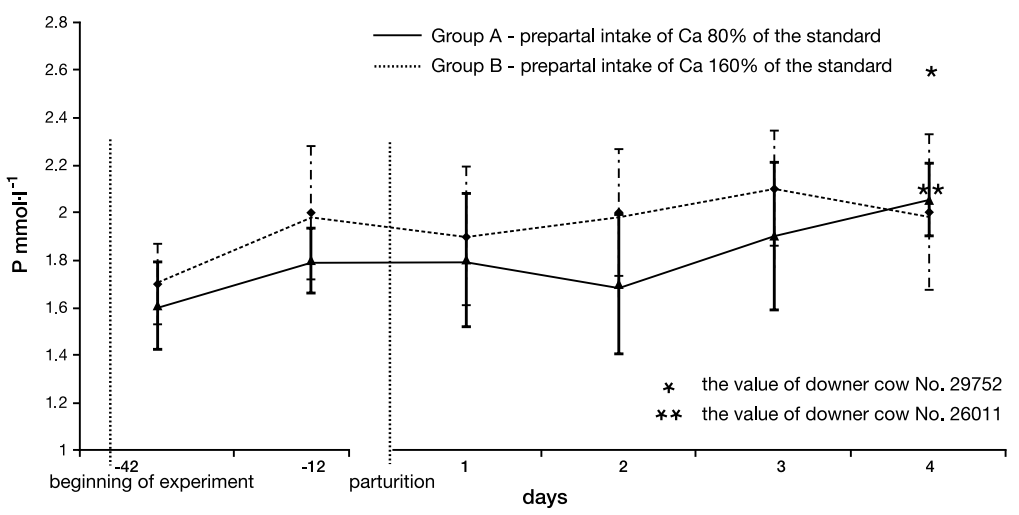

Fig. 2. Pre- and postpartal dynamics of phosphoraemia in dairy cows 


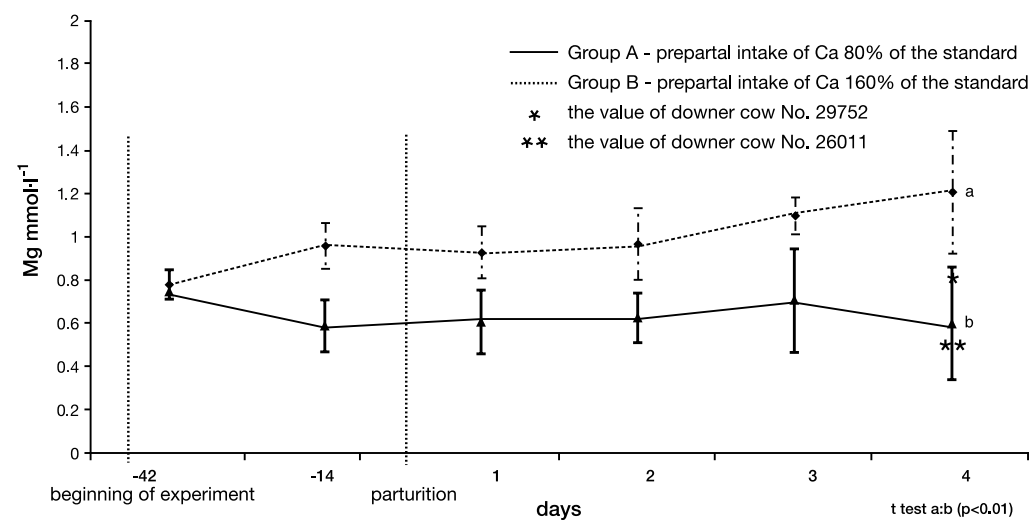

Fig. 3. Pre- and postpartal dynamics of magnesaemia in dairy cows

\section{Discussion}

The results of the nutrition experiment have extended present knowledge (Hallgren 1965) of postpartal hypocalcaemia dynamics at a low intake of $\mathrm{Ca}, \mathrm{P}$ and $\mathrm{Mg}$ in cows at the $8^{\text {th }}$ month of pregnancy. The finding of hypocalcaemia $\left(1.82 \pm 0.10 \mathrm{mmol} \cdot \mathrm{l}^{-1}\right)$ at the beginning of the nutrition experiment, on average 42 days before the expected parturition in groups A and B (Fig. 1) can be explained by a commonly reported decrease in the dry matter intake during the transition from summer to winter ration (Kolb and Gürtler 1971).

In the foothills of Western Bohemia pasture forage is of excellent quality including a high proportion of white clover with a high content of easily utilisable calcium. On the other hand, preserved feeds for the winter season are of worse quality including a lower content and worse utilisability of $\mathrm{Ca}, \mathrm{P}$ and $\mathrm{Mg}$ (Sommer 1994).

Compared to reference data of Slanina (1992) (calcaemia 2.25 - $3.00 \mathrm{mmol} \cdot \mathrm{l}^{-1}$, phosphoraemia $1.60-2.25 \mathrm{mmol} \cdot \mathrm{l}^{-1}$, magnesaemia $0.80-1.07 \mathrm{mmol} \cdot \mathrm{l}^{-1}$ ) at least 20 -day deficiency of $\mathrm{Ca}, \mathrm{P}$ and $\mathrm{Mg}$ in animals of group $\mathrm{A}$ and $\mathrm{B}$ resulted in hypocalcaemia and low values of phosphoraemia and magnesaemia already before the beginning of the nutrition experiment. Hypocalcaemia is accompanied by the activation of parathyroid glands, production of parathormone and gradual taking of macroelements, mainly calcium, out of bones.

Compared to data describing the effect of high or low doses of $\mathrm{Ca}$ immediately before parturition (Kováč 2001; Kraft and Dürr 2001) it is to assume that $160 \%$ and $80 \%$ doses of $\mathrm{Ca}$ were given when considerable amounts of not only $\mathrm{Ca}$ but also $\mathrm{P}$ and $\mathrm{Mg}$ were mobilised from bones. This situation resulted in calcaemia remaining at the value 1.90 $\pm 0.22 \mathrm{mmol}^{-1}$ in group A after 30 days while in group B it increased to $2.20 \pm 0.27 \mathrm{mmol} \cdot \mathrm{l}^{1}$.

On day 1 and 2 post partum group A and B had comparable average levels of calcaemia (Fig. 2). But in group A with a higher variation range of individual values of calcaemia, three animals whose calcaemia values were mostly below the limit of reference range became recumbent within 3 days. Further development of the average value of calcaemia in group A with $80 \%$ intake of Ca was more favourable compared to group B. The average value of calcaemia in group A was statistically significantly higher on day 4 than in group B without the application of calcium products $(500 \mathrm{ml}$ Calcium gluconicum, $250 \mathrm{ml}$ Glyphostan and $50 \mathrm{ml}$ of the vitamin ADE oleosum) in two downer cows (Table 3, Fig. 1). This finding does not contradict the data of the authors (Gebauer 1963; Hallgren 1965; Kolb and Gürtler 1971) who recommended decreasing the Ca intake at the end of pregnancy in order to ensure the activation of parathyroid glands and mobilisation of $\mathrm{Ca}$ 
from bones. On the other hand, in downer cows (Table 3) the administration of Glyphostan contributed to an increase in phosphoraemia while in the others it did not lead to a significant change. Hypomagnesaemia persisted both in downer cows and in the other cows. This finding indicates a possibility of the synergy of other factors including magnesium, effective in the muscular activity. The finding of statistically significant hypomagnesaemia on day 4 post partum is another argument for the participation of hypomagnesaemia in the incidence of the downer cow syndrome in group A with an $80 \%$ intake of $\mathrm{Ca}$. According to the findings in three downer cows in group A the detected hypomagnesaemia excluded the diagnosis of classical periparturient paresis (Kudláč et al. 1995; Doležel et al. 1991; Bednarek et al. 2000). The participation of significant hypomagnesaemia in the downer cow syndrome in group A consists in the effect of $\mathrm{Mg}$ during the transmission of an impulse in the neuromuscular system (Kolb and Gürtler 1971).

The results of the nutrition experiment document that besides hypocalcaemia, greater attention should be paid to hypophosphoraemia and hypomagnesaemia in order to reduce the incidence of postpartal downer cow syndrome.

From the practical aspect it is recommended to base the decision on a transient increase in the prepartal Ca dose on the determination of calcaemia, phosphoraemia and magnesaemia as the indicators of saturation of pregnant cows with these macroelements. In the case of hypocalcaemia, hypophosphoraemia and especially hypomagnesaemia the prepartal administration of low $\mathrm{Ca}$ diet is not recommended.

\section{Dynamika kalcémie, fosforémie a magnezémie při rozdílném prepartálním př́ijmu vápníku u dojených krav}

Cílem práce bylo porovnat účinnost vysokého a nízkého př́ijmu Ca u krav s analyticky definovaným stavem kalcemie, fosforemie a magnezemie v prepartálním období na jejich postpartální změny významné pro diagnostiku poporodních onemocnění.

U dojených krav (Český strakatý skot) byl od 241. dne gravidity při zimní krmné dávce upraven prepartální př́ijem Ca ve skupině $\mathrm{A}(\mathrm{n}=15)$ na $80 \%$ a ve skupině $\mathrm{B}(\mathrm{n}=9)$ na 160 \% normy. U obou skupin byly sledovány koncentrace $\mathrm{Ca}, \mathrm{P}$ a Mg v krevním séru při zahájení experimentálních diet, 12. den před předpokládaným porodem, 1., 2., 3. a 4. den po porodu.

U obou skupin byla při zahájení pokusu ( 42 dnů před porodem) zjištěna hodnota kalcemie $1,82 \pm 0,10 \mathrm{mmol} \cdot \mathrm{l}^{-1}$, fosforemie $1,61 \pm 0,37 \mathrm{mmol} \cdot \mathrm{l}^{-1}$ a magnezemie $0,74 \pm 0,06 \mathrm{mmol} \cdot \mathrm{l}^{-1}$ krevního séra. Po 30 denním podávání experimentální diety (12. den př̀ed předpokládaným porodem) byla zaznamenána ve skupině A výraznější hypokalcemie přetrvávající do třetího dne po porodu. Fosforemie a magnezemie se od 12. dne před předpokládaným porodem do 4. dne po porodu pohybovaly pouze při spodní hranici referenčních hodnot. Ve skupině A došlo u třech krav do 3 . dne po porodu $\mathrm{k}$ ulehnutí s poklesem magnesemie pod $0,5 \mathrm{mmol} \cdot \mathrm{l}^{-1}$.

Ve skupině B se $160 \%$ př́imem Ca odpovídala 12 dnů před předpokládaným porodem kalcemie $2,20 \pm 0,27 \mathrm{mmol} \cdot \mathrm{l}^{-1}$ a hypokalcemie od $1,60 \pm 0,45 \mathrm{do} 1,80 \pm 0,26 \mathrm{mmol} \cdot \mathrm{l}^{-1}$ krevního séra přetrvávala od prvního do čtvrtého dne po porodu. Průměrná úroveň fosforemie se ve skupině $B$ udržovala nad $1,80 \mathrm{mmol} \cdot \mathrm{l}^{-1}$ a magnezemie v rozsahu $0,93-1,21 \mathrm{mmol} \cdot \mathrm{l}^{-1}$ krevního séra.

Z výsledku nutričního pokusu vyplývá, že k prepartální úpravě př́ijmu Ca v zájmu omezení postpartálního ulehnutí je nutno stanovit kalcemii, fosforemii a magnezemii u vysokobřezích krav. Při hypokalcemii, hypofosforemii a zvláště hypomagnesemii se prepartální dieta s $80 \%$ krytí potř̌eby Ca projevuje vyšším rizikem ulehnutí provázeným prohloubením hypomagnezemie. 


\section{Acknowledgement}

We thank the owner of the farm Drouhavec for his excellent technical assistance.

\section{References}

BEDNAREK D, KONDRACKI M, GRZEDA M 2000: Magnesium and calcium in prophylaxis of parturient paresis in dairy cows. Med Wet $56: 367-371$

GEBAUER H 1963: Zur Prophylaxe des Kälberfiebers mit hohen Vitamin - D - Gaben Prakt Tierarzt 44: $391-394$

DOLEŽEL R, KUDLÁČ E, STUDENČIK B, BALAŠTIK J 1991: Biochemical changes in peripheral blood parameters in cows within 45 days after parturition. Vet Med-Czech 36: 265-271

GOFF JP, HORST RL 1993: Oral-administration of calcium salts for treatment of hypocalcaemia in cattle. J Dairy Sci 76: 101- 108

GOFF JP, HORST RL, JARDON PW, BORELLI C, WEDAM J 1996: Field trials of an oral calcium propionate paste as an acid to prevent milk fever in periparturient dairy cows. J Dairy Sci 79: 378-383

GOFF JP, HORST RL 2003: Role of acid-base physiology on the pathogenesis of parturient hypocalcaemia (milk fever) - the DCAD theory in principal and practice. Acta Vet Scand 6: 51-56

HALLGREN W 1965: "Gebärparese”, Begriff, Name, Behandlung, Verhütung. Wien Tierärztliche Monatsschrift 52: 359-369

HENNIG A 1972: Mineralstoffe, Vitamine, Ergotropika. Veb. Dtsch Landw. Verlag, 636 p.

HORST RL, GOFF JP, REINHARDT TA 2003: Role of vitamin D in calcium homeostasis and its use in prevention of bovine periparturient paresis. Acta Vet Scand 97: 35-50

KOLB E, GÜRTLER H 1971: Ernährungsphysiologie der landwirtschaftlichen Nutztiere.Verlag Fischer Jena, $957 \mathrm{p}$.

KOVÁČ G 2001: Choroby hovädzieho dobytka. Vyd. M and M, Prešov, 874 p.

KRAFT W, DÜRR V 2001: Klinická laboratorní diagnostika ve veterinární medicíně. Vyd. Hajko a Hajková, Bratislava, $365 \mathrm{p}$.

KUDLÁČ E, SAKOUR M, ČANDERLE J 1995: Metabolic profile in the peripartal period in cows with afterbirth retention and without it. Vet Med-Czech 40: 201-207

LITTLEDIKE ET, GOFF JP 1987: Interactions of calcium, phosphorus and magnesium and vit D that influence their status in domestic meat animals. J Anim Sci 65: 1727-1743

MATOUŠKOVÁ O, CHALUPA J, CÍGLER M, HRUŠKA K 1992: Statistický systém STAT plus, verze 1.01, uživatelská př́ručka. VÚVeL Brno, 168 p.

SLANINA L 1992: Metabolický profil hovädzieho dobytka vo vztahu k zdraviu a produkcii. 2 vyd. ŠVS SR, ÚVIO Bratislava, $115 \mathrm{p}$.

SOMMER A (Ed.) 1994: Potřeba živin a tabulky výživné hodnoty krmiv pro přežvýkavce. ČZS VÚVZ Pohořelice, $196 \mathrm{p}$.

STOCKDALE CR 2004: Effects of feeding magnesium sulphate to dry pregnant dairy cows with different body condition scores on intake in late gestation, periparturient blood calcium concentrations and production in early lactation. Aust J Exp Agr 44: 539-546

STOJEVIC Z, ZDELAR-TUK M, MILINKOVIC-TUR S, PIRSLJIN J, BEER-LJUBIC B, POLJICAK-MILAS N 2004: Changes of calcium, phosphorus, magnesium in the blood plasma of dairy cows during lactation and the drying period. Tieraertzl Umsch 59: 444-448

UNDERWOOD EJ, SUTTLE NF 2001: The mineral Nutrition of Livestock, 3rd. edition CABI, Publishing, New York, $614 \mathrm{p}$.

VOJTÍŠEK B, HRONOVÁ B, HAMŘÍK J, JAMBOR V, ZEZULA V, ZENDULKA I, DVOŘÁK R, ŠIŠÁK M 1991: The Effects of Clover-Grass Silage Treated with Acrylic Acid on Some Parameters of Cows Metabolism at the Time of Parturition and the State in their Cows. Vet Med-Czech 36: 273-280 